\title{
Kemampuan Berpikir Kreatif Mahasiswa dalam Menyelesaikan Soal-soal Open-Ended
}

\author{
Diyah Hoiriyah* \\ Fakultas Tarbiyah dan Ilmu Keguruan, Institut Agama Islam Negeri \\ Padangsidimpuan \\ diyah@iain-padangsidimpuan.ac.id
}

\begin{abstract}
The purpose of this study is to describe the creative thinking ability of Tadris/ Mathematics Education students in Padangsidimpuan IAIN in solving open-ended problems. The approach used is a descriptive qualitative approach that seeks to analyze the ability of students to think creatively in solving open-ended problems. The research subjects were students of the third semester of the Tadris / Mathematics Education Study Program at IAIN Padangsidimpuan. The research subjects consisted of 6 students consisting of 2 students in the high category, 2 students in the medium category, and 2 students in the low category. Data collection techniques in the form of observation, tests and interviews. Data analysis is performed by data reduction, data presentation and verification or conclusions. The data validity technique is done by triangulating data sources. The results showed that students' creative thinking ability for high category was very good in solving open-ended mathematics problems. The ability of students to think creatively for the category is in good criteria. The ability of students to think creatively for low categories as a whole is in poor criteria. Overall for low ability students still need coaching.
\end{abstract}

Keywords: mathematics; mathematical ability; creative thinking; creative thinking skills; open-ended

\begin{abstract}
Abstrak
Penelitian ini bertujuan untuk mendeskripsikan kemampuan berpikir kreatif mahasiswa Tadris/ Pendidikan Matematika IAIN Padangsidimpuan dalam menyelesaikan soal-soal open-ended. Pendekatan yang digunakan adalah pendekatan kualitatif deskriptif yang berupaya menganalisis kemamuan berpikir kreatif mahasiswa dalam menyelesaikan soal open-ended. Subjek penelitian adalah mahasiswa semester III Program Studi Tadris/Pendidikan Matematika IAIN Padangsidimpuan. Subjek penelitian berjumlah 6 mahasiswa yang terdiri dari 2 mahasiswa dengan kategori tinggi, 2 mahasiswa dengan kategori sedang, dan 2 mahasiswa dengan kategori rendah. Teknik pengumpulan data berupa observasi, tes dan wawancara. Analisis data dilakukan dengan reduksi data, penyajian data dan verifikasi atau kesimpulan. Teknik keabsahan data dilakukan dengan triangulasi sumber data. Hasil penelitian menunjukkan kemampuan berpikir kreatif mahasiswa untuk kategori tinggi sangat baik dalam menyelesaikan masalah matematika open-ended. Kemampuan berpikir kreatif mahasiswa untuk kategori sedang berada pada kriteria baik. Kemampuan berpikir kreatif mahasiswa untuk kategori rendah secara keseluruhan berada pada kriteria kurang baik. Secara keseluruhan untuk mahasiswa kemampuan rendah masih perlu pembinaan.
\end{abstract}

Kata Kunci: matematika; kemampuan matematika; berpikir kreatif; kemampuan berpikir kreatif; open-ended.

*Correspondence:

Email: diyah@iain-padangsidimpuan.ac.id 


\section{PENDAHULUAN}

Matematika merupakan salah satu ilmu pengetahuan yang diajarkan di setiap jenjang pendidikan mulai dari sekolah dasar hingga ke perguruan tinggi. Baik matematika itu merupakan mata pelajaran tersendiri atau matematika itu tidak terlepas dari mata pelajaran lainnya. Dengan kata lain, matematika itu merupakan ratunya ilmu dan sekaligus pelayan bagi ilmu-ilmu lainnya. Dikatakan matematika sebagai ratunya ilmu, karena matematika itu sebagai sumber dari ilmu-ilmu yang lain. Dimana matematika itu memiliki peranan penting dalam membangun kemampuan berpikir dan berlogika siswa, sehingga menjadi alat bantu dan pelayanan ilmu untuk kepentingan teoritis maupun kepentingan praktis dalam pemecahan masalah sehari-hari sebagai bentuk aplikasi matematika (Tarigan, 2012). Dan hampir setiap atau banyak ilmu lainnya yang penemuan dan pengembangn ilmunya bergantung dari ilmu matematika itu sendiri. Selain itu, matematika juga berkaitan langsung dengan kehidupan sehari-hari manusia, seperti memecahan persoalan-persoalan dalam kehidupan sehari-hari manusia.

Berdasarkan hal tersebut di atas, nampak jelas bahwa matematika memiliki peranan yang sangat penting dalam perkembangan IPTEK dalam dewasa ini. Semakin maju teknologi sains maka akan semakin banyak penggunaan ilmu matematika itu sendiri. Dan dalam pengembangan IPTEK tersebut, sejatinya seseorang pasti memerlukan kemampuan berpikir tingkat tinggi yaitu berpikir kritis, logis, analistis, sistematis dan kreatif.

Menurut (Undang-Undang NO. 20, 2003), berpikir kreatif merupakan salah satu tujuan pendidikan nasional yaitu berkembangnya potensi peserta didik agar menjadi manusia yang kreatif. Oleh karenanya, pengajaran matematika sudah seharusnya berpusat kepada pengembangan kemampuan berpikir tingkat tinggi matematis seorang anak yaitu kreativitas matematik.

Dengan demikian kemampuan berpikir kreatif merupakan salah satu ciri kognitif dari kreativitas dan tergolong pada kompetensi tingkat tinggi (high order competencies) dan dapat dipandang sebagai kelanjutan dari kompetensi dasar (biasa disebut dengan basic skills dalam pembelajaran matematika). Kemampuan berpikir kreatif adalah bagaimana seseorang mampu ataupun bisa menemukan solusi-solusi atau penyelesaian yang hampir menurutnya tidak ada dalam suatu permasalahan matematika. Sehingga dia berpikir untuk mencari solusi-solusi tersebut dalam memecahkan masalah yang dihadapinya. Proses dalam menemukan dan mencari solusi-solusi tersebutlah yang dikatakan sebagi proses berpikir kreatif yang pastinya membutuhkan kreativitas seorang anak dalam hal ini mahasiswa untuk menghasilkan ide-ide ataupun gagasan baru.

Menurut Sumarmo (Utari Sumarmo, 2013), kemampuan berpikir kreatif adalah kemampuan esensial yang perlu dimiliki oleh dan dikembangkan pada siswa yang belajar matematika karena kemampuan tersebut sesuai dengan visi 
matematika, tujuan pendidikan nasional dan tujuan pembelajaran matematika sekolah dan diperlukan untuk menghadapi suasana bersaing yang semakin ketat. Selanjutnya Suryadi dan Herman (Suryadi, D., \& Herman, 2008) menjelaskan bahwa kemampuan berpikir kreatif merupakan suatu proses berpikir untuk mengungkapkan hubungan-hubungan baru, melihat sesuatu dari sudut pandang baru dan membentuk kombinasi baru dari dua konsep atau lebih yang sudah dikuasai sebelumnya. Kemudian Pehkonen (Huda, 2011), memandang berpikir kreatif sebagai suatu kombinasi dari berpikir logis dan berpikir divergen yang didasarkan pada intuisi tetapi masih dalam kesadaran. Maksud berpikir divergen sendiri adalah memberikan bermacam-macam kemungkinan jawaban dari pertanyaan yang sama. Dengan demikian kemampuan berpikir kreatif dipandang sebagai kemampuan menempatkan sejumlah objek-objek yang ada dan mengombinasikannya menjadi bentuk yang berbeda untuk tujuan-tujuan yang baru. Sementara itu Munandar (Huda, 2011) juga menjelaskan pengertian berpikir kreatif yaitu sebagai kemampuan menemukan banyak kemungkinan jawaban terhadap suatu masalah, dimana penekanannya pada kuantitas, ketepatgunaan, dan keberagaman jawaban. Pengertian ini menunjukkan bahwa kemampuan berpikir kreatif seseorang akan semakin tinggi, jika ia mampu menunjukkan banyak kemungkinan jawaban pada suatu masalah. Tetapi semua jawaban itu harus sesuai dengan masalah dan tepat, selain itu jawabannya harus bervariasi.

Berdasarkan beberapa pengertian di atas menunjukkan bahwa kemampuan berpikir kreatif dapat membantu mahasiswa untuk menciptakan ide-ide/gagasan baru ataupun menemukan inovasi-inovasi baru yang lebih kreatif dan inovatif berdasarkan pengetahuan yang telah dimilikinya sendiri untuk menyelesaikan dan menemukan jawaban dari permasalahan-permasalahan matematika yang ada berdasarkan dari sudut pandang yang berbeda-beda. Sehingga dapat disimpulkan bahwa kemampuan berpikir kreatif dapat diartikan sebagai kemampuan menciptakan sesuatu yang baru, atau kemampuan menempatkan dan mengkombinasikan sejumlah objek secara berbeda yang berasal dari pemikiran manusia dalam hal ini mahasiswa yang bersifat dapat dimengerti, berdaya guna, dan inovatif dengan berbagai macam faktor-faktor yang dapat mempengaruhi. Sejalan dengan hal tersebut di atas, maka (Anwar, 2012) berpendapat bahwa berpikir kreatif adalah cara baru dalam melihat dan mengerjakan sesuatu yang memuat 4 aspek antara lain fluency (kefasihan), flexybility (keluwesan), originality (keaslian), dan elaboration (keterincian). Ke empat aspek tersebutlah yang akan dikembangkan sebagai inkator dari kemampuan berpikir kreatif. Adapun yang menjadi unsur-unsur dari kemampuan berpikir kreatif dapat dilihat pada Tabel.1 berikut ini: 
Tabel. 1 Unsur-unsur Berpikir Kreatif

\begin{tabular}{|c|c|}
\hline Pengertian & Perilaku Mahasiswa \\
\hline $\begin{array}{l}\text { Berpikir Lancar (A): } \\
\text { Mencetuskan banyak gagasan, } \\
\text { jawaban, ataupun } \\
\text { penyelesaian. } \\
\text { Selalu memikirkan lebih dari } \\
\text { satu jawaban. }\end{array}$ & $\begin{array}{l}>\text { Mengajukan banyak pertanyaan. } \\
>\text { Menjawab dengan sejumlah jawaban jika ada pertanyaan. } \\
>\text { Mempunyai banyak gagasan mengenai suatu masalah. } \\
>\text { Lancar dalam menggunakan gagasan-gagasannya. } \\
>\text { Bekerja lebih cepat dan melakukan lebih banyak daripada } \\
\text { mahasiswa lain. } \\
>\text { Dengan cepat melihat kesalahan dan kelemahan dari suatu } \\
\text { objek atau situasi. }\end{array}$ \\
\hline $\begin{array}{l}\text { Berpikir Luwes (B): } \\
\text { Menghasilkan gagasan, } \\
\text { jawaban atau pertanyaan yang } \\
\text { bervariasi. } \\
\text { Dapat melihat suatu masalah } \\
\text { dari sudut pandang yang } \\
\text { berbeda-beda. } \\
\text { Mencari banyak alternatif } \\
\text { atau arah yang berbeda-beda. } \\
\text { Mampu mengubah cara } \\
\text { pendekatan atau pemikiran. }\end{array}$ & $\begin{array}{l}\text { Memberikan aneka ragam penggunaan yang tak lazim } \\
\text { terhadap suatu objek. } \\
\text { Memberikan macam-macam penafsiran terhadap suatu } \\
\text { gambar, cerita atau masalah. } \\
\text { Denerapkan suatu konsep atau asas dengan cara yang } \\
\text { berbeda-beda. } \\
>\text { Memberikan pertimbangan atau mendiskusikan sesuatu } \\
\text { selalu memiliki posisi yang berbeda atau bertentangan } \\
\text { dengan mayoritas kelompok. } \\
>\text { Jika diberi suatu masalah biasanya memikirkan macam- } \\
\text { macam cara yang berbeda-beda untuk menyelesaikannya. } \\
\text { Menggolongkan hal-hal yang menurut pembagian atau } \\
\text { kategori yang berbeda-beda. } \\
>\text { Mampu mengubah arah berpikir secara spontan. }\end{array}$ \\
\hline $\begin{array}{l}\text { Berpikir Orisinal }(\mathrm{C}) \text { : } \\
\text { Mampu melahirkan ungkapan } \\
\text { yang baru dan unik. } \\
\text { Memikirkan cara-cara yang } \\
\text { tak lazim untuk } \\
\text { mengungkapkan diri. } \\
\text { Mampu membuat kombinasi- } \\
\text { kombinasi yang tak lazim dari } \\
\text { bagian-bagian atau unsur- } \\
\text { unsur. }\end{array}$ & $\begin{array}{l}\text { Memikirkan masalah-masalah atau hal yang tak pernah } \\
\text { terpikirkan orang lain. } \\
>\text { Mempertanyakan cara-cara lama dan berusaha } \\
\text { memikirkan cara-cara baru. } \\
>\text { Memilih a-simetri dalam membuat gambar atau desain. } \\
>\text { Mencari pendekatan baru dari stereotype. } \\
>\text { Setelah mendengar atau membaca gagasan, bekerja untuk } \\
\text { mendapatkan penyelesaian yang baru. }\end{array}$ \\
\hline $\begin{array}{l}\text { Berpikir Elaboratif }(\mathrm{D}) \text {. } \\
\text { Mampu berkarya dan } \\
\text { mengembangkan } \\
\text { produk atau gagasan. } \\
\text { Menambahkan } \\
\text { memperinci detaildetail dari } \\
\text { suatu objek, gagasan atau } \\
\text { situasi sehingga menjadi lebih } \\
\text { menarik. }\end{array}$ & $\begin{array}{l}\text { Mencari arti yang lebih mendalam terhadap jawaban atau } \\
\text { pemecahan masalah dengan melakukan langkah-langkah } \\
\text { yang terperinci. } \\
>\text { Mengembangkan/memperkaya gagasan orang lain. } \\
>\text { Mencoba untuk menguji detail-detail untuk melihat arah } \\
\text { yang akan ditempuh. } \\
>\text { Mempunyai rasa keadilan yang kuat sehingga tidak puas } \\
\text { dengan penampilan yang kosong/sederhana. } \\
>\text { Menambah garis-garis/warna dan detail-detail/bagian- } \\
\text { bagian terhadap gambar sendiri. }\end{array}$ \\
\hline
\end{tabular}


Berdasarkan unsur-unsur berpikir kreatif tersebut, jelas sekali sangat menuntut mahasiswa untuk kreatif dalam berpikir. Kreatif dalam berpikir tentu menyebabkan mahasiswa harus kreatif juga dalam berkreatifitas. Mengingat kreatifitas manusia dalam menyelesaikan masalah akan berbeda-beda tergantung dari pengetahuan dan sudut pandang mereka masing-masing, maka kreatifitas mahasiswa dalam memecahkan masalah matematikapun pasti terbuka dan akan berbeda-beda tergantung dari pengetahuan dan kemampuan mereka masingmasing. Tergantung bagaimana mereka menafsirkan masalah tersebut dan bagaimana mereka menuangkan pengetahuan mereka terhadap masalah-masalah tersebut.

Semakin tinggi tingkat berpikir kreatif anak dalam hal ini mahasiswa, maka akan ada kemungkinan semakin bagus dia mampu menciptakan inovasiinovasi baru yang lebih kreatif dan imajinatif. Hal ini sejalan dengan yang diungkapkan oleh Yunianta, dkk (Yunianta, Rusilowati, \& Rochmad, 2012) bahwa sedikitnya orang-orang yang berpikir kreatif ditandai dengan rendahnya inovasi dan kreasi baru oleh masyarakat umum. Dengan demikian, rendahnya inovasi dan kreasi baru itu menunjukkankan bahwa rendahnya tingkat berpikir kreatif seseorang.

Padahal kita ketahui bahwa inovasi dan kreasi baru sangatlah dipandang penting dalam mutu pendidikan ini. Mampunya seorang mahasiswa menciptakan inovasi dan kreasi baru maka akan dapat mewujudkan salah satu cita-cita kemerdekaan bangsa yaitu mencerdaskan anak bangsa. Untuk itu, sarana yang dipandang mampu untuk mendukung berpikir kreatif dalam menciptakan inovasi dan kreasi baru tersebut adalah dengan menyajikan soal-soal matematika yang open-ended. Berdasarkan hasil penelitian (Elly's Mersina Mursidik, Nur Samsiyah, 2014; Fardah, 2012; Samsiyah, 2015; Yuliana, 2015) yang menyatakan bahwa pemberian soal-soal open-ended pada proses pembelajaran matemtika dapat menumbuhkembangkan proses berpikir kreatif siswa serta membuat siswa lebih kreatif dalam menyelesaikan permasalahan-permasalahan di dalam matematika tersebut. Selanjutnya Heddens dan Speer (dalam Mustikasari, 2010) mengungkapkan bahwa dengan pemberian soal terbuka, dapat memberi rangsangan kepada siswa untuk meningkatkan cara berpikirnya, siswa memiliki kebebasan untuk mengekspresikan hasil eksplorasi daya nalar dan analisanya secara aktif dan kreatif dalam upaya menyelesaikan suatu permasalahan. Selain itu berdasarkan penelitian (Eline Yanty Putri Nasution, 2017) ditemukan bahwa pendekatan open-ended dapat meningkatkan kemampuan berpikir kreatif siswa dalam pembelajaran matematika. Dengan demikian pemberian soal-soal openended ini dapat dipandang mampu untuk merangsang dan menumbuhkembangkan berpikir kreatif mahasiswa dalam menyelesaikan soal-soal matematika sehingga mampu menciptakan dan mencetuskan ide-ide serta kreasi baru dalam proses pembelajaran matematika. 
Soal-soal open-ended yang dimaksud disini adalah bentuk soal matematika yang terbuka, yang memiliki banyak penyelesaian dan bervariasi jawaban. Masalah open-ended menurut (Foong, 2002) sebagai "struktur yang cacat" karena terdiri dari data yang hilang atau asumsi-asumsi tanpa prosedur yang tetap dan tidak menjamin solusi yang tepat. Selanjutnya menurut (Suherman, 2003) problem yang diformulasikan memiliki multi jawaban yang benar disebut problem tak lengkap atau disebut juga open-ended problem (soal terbuka).

Adapun tujuan dari pembelajaran open-ended menurut Nohda (Suherman, 2003) adalah untuk membantu mengembangkan kegiatan kreatif dan pola pikir matematis siswa melalui problem solving secara simultan. Berdasarkan tujuan pembelajaran open-ended tersebut maka dengan memberikan soal-soal openended di saat kegiatan pembelajaran berlangsung akan dapat membawa mahasiswa untuk menjawab permasalahan dengan banyak cara dan mungkin juga banyak jawaban yang benar diperoleh mahasiswa sehingga dapat mengundang, merangsang dan menumbuhkembangkan potensi intelektual, pengalaman dan pola pikir mahasiswa yang kreatif dalam proses menemukan ataupun menciptakan sesuatu yang baru. Selain itu, pemberian soal-soal terbuka ataupun soal-soal open-ended, dapat memberi kesempatan kepada mahasiswa untuk memiliki kebebasan yang seluas-luasnya dalam mengekspresikan hasil eksplorasi daya nalar dan analisanya secara aktif dan kreatif dalam upaya kemampunannya untuk menyelesaikan suatu permasalahan matematika sehingga melahirkan ataupun menciptakan ide-ide ataupun kreasi baru. Dimana dalam proses pembelajarannya kita tidak terfokus untuk menilai pada hasil akhir jawaban mahasiswa saja, melainkan pada proses penyelesaiannya dalam menemukan jawaban-jawaban yang hingga memungkinkan mampu menemukan formula ataupun ide-ide baru berdasarkan pola pikirnya. Penyelesaian-penyelesaian tersebutlah yang diharapkan mampu mengantarkan mahasiswa untuk berpikir kreatif hingga berdasarkan pemikiran dan pengetahuanya tersebut menghasilkan jawaban yang benar bahkan beraneka ragam.

Mengingat kreatifitas manusia dalam menyelesaikan masalah akan berbeda-beda tergantung dari pengetahuan dan sudut pandang mereka masingmasing, maka kreatifitas mahasiswa dalam memecahkan masalah matematika terbuka akan berbeda tergantung dari pengetahuan dan kemampuan mereka masingmasing. Perbedaan proses berpikir kreatif ini perlu dikaji secara mendalam sehingga dapat digunakan sebagai acuan bagi guru dan dosen dalam mengembangkan pembelajaran matematika. Dan berdasarkan hal tersebut nantinya dapat membuat guru atapun dosen untuk merangsang atau memberi stimulasi positif terhadap kemampuan berpikir kreatif mahasiswa sehingga mahasiswa tertarik mengerjakan soal-soal open-ended. 


\section{METODE PENELITIAN}

Jenis penelitian ini adalah penelitian kualitatif (Lexi J. Moleong, 2006; Sukmadinata, 2009) deskriftif (Agung, 2014) yang bertujuan untuk mengetahui kemampuan berpikir kreatif mahasiswa dalam menyelesaikan soal-soal openended. Subyek dalam penelitian ini adalah 6 mahasiswa semester III Tadris/Pendidikan Matematika IAIN Padangsidimpuan. Teknik pengambilan subyek adalah teknik stratified random sampel. Sumber data didapat dari hasil observasi, tes dan wawancara. Teknik pengumpulan data yang digunakan dalam penelitian ini adalah dengan metode observasi, tes dan wawancara.

Dalam penelitian ini, peneliti menggunakan observasi partisipatif kategori aktif. Dan tes yang digunakan adalah soal-soal matematika yang open-ended. Metode ini digunakan untuk mengetahui profil berpikir kreatif mahasiswa dalam menyelesaikan soal-soal open-ended. Data yang diharapkan berupa hasil pekerjaan mahasiswa pada lembar jawaban yang disertai dengan langkahlangkahnya. Data yang didapatkan dari tes ini digunakan sebagai bahan analisis mengenai cara berpikir kreatif mahasiswa.

Sementara untuk wawancara, peneliti menggunakan wawancara semiterstruktur dimana dalam pelaksanaannya lebih bebas dengan tujuan untuk menemukan permasalahan mahasiswa secara lebih terbuka, dimana pihak yang diajak wawancara diminta pendapat dan ide-idenya. Dalam hal ini peneliti mengajukan pertanyaan-pertanyaan yang terkait dengan tujuan penelitian yaitu untuk mendapatkan profil berpikir kreatif mahasiswa dalam menyelesaikan masalah matematika open-ended.

Data-data yang diperoleh dianalisi dengan teknik triagulasi yaitu:

1. Data reduction (Reduksi Data), data yang diperoleh dari lapangan jumlahnya cukup banyak, untuk itu maka perlu segera dilakukan analisis data melalui reduksi data. Mereduksi data berarti merangkum, memilih hal-hal yang pokok, memfokuskan pada hal-hal yang penting, dicari tema dan polanya. Dengan demikian data yang telah direduksi akan memberikan gambaran yang lebih jelas dan mempermudah peneliti untuk melakukan pengumpulan data selanjutnya, dan mencarinya bila diperlukan.

2. Data display (Penyajian Data), setelah data direduksi, maka langkah selanjutnya adalah mendisplaykan atau menyajikan data. Dalam penelitian kualitatif, penyajian data dilakukan dalam bentuk uraian singkat, bagan, hubungan antar kategori.

3. Conclusion drawing/verification (Penarikan kesimpulan dan verifikasi), langkah selanjutnya dalam analisis data kualitatif adalah penarikan kesimpulan dan verifikasi. 


\section{HASIL DAN PEMBAHASAN}

Hasil analisis kemampuan berpikir kreatif mahasiswa dirangkum pada Tabel. 2 berikut ini berdasarkan jawaban mahasiswa dalam menyelesaikan soalsoal matematika open-ended dan berdasarkan hasil wawancara peneliti dengan para subyek dalam hal ini mahasiswa:

Tabel 2. Tabel Kategori Kreativitas Subyek

\begin{tabular}{|c|c|c|c|c|c|}
\hline \multirow{2}{*}{ Subyek } & \multirow{2}{*}{ Kategori } & \multicolumn{4}{|c|}{ Kode Unsur Berpikir Kreatif } \\
\cline { 3 - 6 } & & A & B & C & D \\
\hline S1 & Tinggi & SB & B & SB & SB \\
\hline S2 & Tinggi & SB & B & SB & SB \\
\hline S3 & Sedang & SB & B & B & B \\
\hline S4 & Sedang & B & B & B & B \\
\hline S5 & Rendah & KB & B & KB & B \\
\hline S6 & Rendah & B & KB & B & KB \\
\hline
\end{tabular}

Ket:

SB : Sangat Baik

B : Baik

KB : Kurang Baik

Berdasarkan tabel di atas, dapat dilihat bahwa kemampuan berpikir kreatif mahasiswa untuk kategori tinggi pada aspek berpikir lancar sangat baik karena mahasiswa kategori tinggi mampu mencetuskan lebih dari satu ide ataupun gagasan dalam menyelesaikan dan menjawab masalah matematika open-ended. sehingga pada aspek berpikir lancar untuk mahasiswa kategori tinggi tidak mengalami kesulitan dalam mencetuskan ide-idenya. Untuk aspek berpikir luwes, mahasiswa pada kategori tinggi berada pada kriteria baik artinya pada umumnya mampu menentukan satu cara dalam menyelesaikan masalah matematika openended. Mahasiswa pada kategori tinggi untuk aspek keaslian berada pada kriteria sangat baik karena mahasiswa mampu melahirkan ungkapan baru dan unik serta memiliki cara-cara yang tak lazim dan mampu membuat kombinasi-kombinasi yang tak lazim dari bagian-bagian atau unsur-unsur dalam menyelesaikan masalah-masalah open-ended. Kemudian untuk kemampuan mahasiswa pada aspek berpikir elaboratif, mahasiswa kategori tinggi memiliki aspek berpikir elaboratif juga sangat baik, artinya mahasiswa dapat memperjelas penyelesaian dengan rinci dan tepat terhadap suatu karya ataupun produk yang dihasilkannya, sehingga pada aspek ini secara umum tidak mengalami kesulitan.

Selanjutnya, kemampuan berpikir kreatif mahasiswa untuk kategori sedang pada aspek berpikir lancar baik karena mahasiswa kategori sedang mampu 
memunculkan satu ide dalam menyelesaikan masalah matematika open-ended sehingga pada aspek berpikir lancar untuk mahasiswa kategori sedang tidak terlalu mengalami kesulitan. Untuk aspek berpikir luwes, mahasiswa pada kategori sedang juga berada pada kriteria baik artinya pada umumnya mampu menentukan satu cara dalam menyelesaikan masalah matematika open-ended. Mahasiswa pada kategori sedang untuk aspek keaslian pada umumnya berada pada kriteria baik juga artinya mahasiswa dalam menggunakan cara dalam menyelesaikan masalah minimal menggunakan cara yang umum dan mengarah pada penyelesaian. Kemampuan pada aspek berpikir elaboratif pada mahasiswa kategori sedang berada pada kriteria baik juga, artinya mahasiswa hanya dapat memperinci penjelasan dengan seadanya.

Kemudian, kemampuan berpikir kreatif mahasiswa untuk kategori rendah secara keseluruhan berada pada kriteria kurang baik. Pada aspek berpikir lancar hasil analisis pada mahasiswa kategori rendah maksimal hanya mampu memunculkan satu ide dalam menyelesaikan masalah matematika open-ended sehingga pada aspek berpikir lancar untuk mahasiswa kategori rendah mengalami kesulitan. Untuk aspek berpikir luwes, mahasiswa pada kategori rendah pada umumnya hanya mampu menentukan satu cara dalam menyelesaikan masalah matematika open-ended. Untuk aspek keaslian mahasiswa dalam menggunakan cara dalam menyelesaikan masalah pada umumnya menggunakan cara yang biasa digunakan dan tidak mengarah mengarah pada penyelesaian. Kemampuan pada aspek berpikir elaboratif pada mahasiswa kategori rendah maksimal hanya dapat memperinci dengan penjelasan yang dapat dipahami tetapi kurang tepat. Secara keseluruhan untuk mahasiswa kemampuan rendah masih perlu pembinaan. Dan perlu untuk dibimbing dan diberikan latihan yang lebih sering lagi. Perlu untuk lebih banyak membahas soal-soal open-ended agar terbiasa dan pola pikir mahasiswanya dapat terbuka untuk lebih kreatif lagi.

Kemudian berdasarkan hasil wawancara peneliti dengan para mahasiswa, diperoleh bahwa kesulitan mahasiswa yang ditemukan peneliti terdapat pada mahasiswa kategori rendah yaitu mereka merasa kesulitan dalam memecahkan soal-soal open-ended itu karena kurang bijak dan kreatif dalam mengembangkan jawaban yang telah diperoleh. Susah memahami soal-soal yang diberikan sehingga kurang mampu merubah soal-soal tersebut ke dalam model matematika. Kurang terbiasa memikirkan cara-cara yang tak lazim dalam menyelesaikan masalah. Masih selalu terfokus pada rumus yang biasa digunakan, sehingga cenderung menghapal yang menyebabkan mereka lebih tertutup pikirannya untuk lebih kreatif dalam membuat solusi-solusi penyelesaian.

Namun untuk secara keseluruhan, pemberian soal-soal open-ended dalam pembelajaran matematika ini berada pada kategori baik, baik untuk mahasiswa kategori tinggi, ataupun sedang yang berarti berpikir kreatif mahasiswa dikategorikan baik, baik dia dalam unsur berpikir lancar, berpikir luwes, berpikir 
orisinal dan berpikir elaboratif. Dengan demikian dapat dikatakan bahwa pemberian soal-soal open-ended kepada mahasiswa dapat merangsang dan menumbungkembangkan kemampuan berpikir kreatif mahasiswa sehingga mampu melahirkan ataupun menciptakan ide-ide baru yang inovatif dan kreatif yang ada pada dirinya dalam memecahkan permasalah-permasalahan matematika.. Sedangkan untuk mahasiswa kategori rendah masih kurang baik. Rendah, sehingga perlu untuk pembinaan yang lebih khusus lagi.

Temuan-temuan peneliti tersebut di atas sejalan dengan temuan peneliti lainnya yaitu penelitian (Elly's Mersina Mursidik , Nur Samsiyah, 2014; Fardah, 2012; Samsiyah, 2015; Yuliana, 2015) yang menyatakan bahwa pemberian soalsoal open-ended dapat menumbuhkembangkan kemampuan berpikir kreatif siswa. Namun terdapat perbedaan dalam penelitian ini dengan penelitian lainnya yaitu subyek dan materi yang diajarkan dalam penelitian ini berbeda, sehingga terdapat perbedaan hasil yang ditemukan pada unsur-unsur berpikir kreatifnya. Baik dalam hal berpikir berpikir lancar, berpikir luwes, berpikir orisinal dan berpikir elaboratif terdapat perbedaan hasil dalam penelitian ini dengan penelitian sebelumnya. Namun secara keseluruhan sama-sama soal-soal open-ended dapat menumbuhkembangkan berpikir kreatif mahasiswa.

\section{KESIMPULAN}

Berdasarkan hasil penelitian dan pembahasan dapat diambil kesimpulan sebagai berikut yaitu hasil penelitian menunjukkan bahwa kemampuan berpikir kreatif mahasiswa untuk kategori tinggi pada aspek berpikir lancar sangat baik karena mahasiswa kategori tinggi mampu memunculkan lebih dari satu ide dalam menyelesaikan masalah matematika open-ended. Untuk aspek berpikir luwes, mahasiswa pada kategori tinggi berada pada kriteria baik artinya pada umumnya mampu menentukan satu cara dalam menyelesaikan masalah matematika openended. Aspek keaslian berada pada kriteria sangat baik artinya cara yang digunakan dalam menyelesaikan masalah adalah dengan cara-cara yang tak lazim dalam menyelesaikan masalah. Dan kemampuan pada aspek berpikir elaboratif juga sangat baik, artinya mahasiswa dapat memperjelas penyelesaian dengan rinci dan tepat. Kemampuan berpikir kreatif mahasiswa untuk kategori sedang pada aspek berpikir lancar, berpikir luwes, berpikir orisinil, dan berpikir elaboratif berada pada kriteria baik artinya mahasiswa dapat memperinci penjelasan dengan tepat. Kemampuan berpikir kreatif mahasiswa untuk kategori rendah secara keseluruhan berada pada kriteria kurang baik. Secara keseluruhan untuk mahasiswa kemampuan rendah masih perlu pembinaan dan perlu untuk lebih banyak latihan-latihan dan pembiasaan menghadapi soal-soal open-ended lagi agar bertumbuh kemampuan berpikir kreatif siswanya. 


\section{DAFTAR PUSTAKA}

Agung, A. A. G. (2014). Metode Penelitian Pendidikan. Malang: Aditya Media Publishing.

Anwar, N. M. E. al. (2012). Relationship of Creative Thinking with Academc Achievements of secondary School Students. International Interdiciplinary Journal of Education, 1(3).

Eline Yanty Putri Nasution. (2017). Interaksi antara Peningkatan Kemampuan Berpikir Kreatif Siswa dengan Pendekatan Open-Ended dan Kemampuan Awal Matematis (KAM) Siswa. Logaritma: Jurnal Ilmu-Ilmu Pendidikan Dan Sains, 5(01), 37-54.

Elly's Mersina Mursidik , Nur Samsiyah, H. E. R. (2014). Analisis kemampuan Berpikir Kreatif Siswa SD dalam Memecahkan Masalah Matematika OpenEnded Ditinjau dari Tingkat Kemampuan Matematika. JURNAL LPPM, 2(1), $7-13$.

Fardah, D. K. (2012). Analisis Proses dan Kemampuan Berpikir Kreatif Siswa dalam Matematika Melalui Tugas Open-Ended. JURNAL KREANO, 3(2).

Foong, P. . (2002). The role of problems to enhance pedagogical practice. The Mathematics Educator, 6(2), 15-31.

Huda, C. (2011). Meningkatkan Kemampuan Berpikir Kreatif Siswa dalam Memecahkan Masalah Matematika dengan Model Pembelajaran Treffinger pada Materi Pokok Keliling dan Luas Persegipanjang. Sunan Ampel.

Lexi J. Moleong. (2006). Metodologi Penelitian Kualitatif. Bandung: Rosda.

Mustikasari. (2010). Pengembangan Soal- Soal Open-Ended Pokok Bahasan Bilangan Pecahan Di sekolah Menengah Pertama. Jurnal Pendidikan Matematika, 4(1), 45-53.

Samsiyah, N. (2015). Kemampuan Berpikir Kreatif dalam Memecahkan Masalah Matematika Open-ended Ditinjau dari Tingkat Kemampuan Matematika pada Siswa Sekolah Dasar. JOURNAL PEDAGOGIA, 4(1), 23-33.

Suherman, E. (2003). Strategi Pembelajaran Matematika Kontemporer. Bandung: JICA UPI.

Sukmadinata, N. S. (2009). Metode Penelitian Pendidikan. Bandung: Remaja Rosdakarya.

Suryadi, D., \& Herman, T. (2008). Eksplorasi Matematika Pembelajaran Pemecahan Masalah. Jakarta: Karya Duta Wahana.

Tarigan, D. E. (2012). Analisis kemampuan pemecahan masalah matematika 
berdasarkan langkah-langkah POLYA pada materi sistem persamaan linear dua variabel bagi siswa kelas VIII SMP negeri 9 Surakarta ditinjau dari kemampuan penalaran siswa. Surakarta: Universitas Sebelas Maret.

Undang-Undang NO. 20. (2003). tentang Sistem Pendidikan Nasional.

Utari Sumarmo. (2013). Pengembangan Kemampuan dan Disposisi Kritis dan Kreatif Peserta Didik dalam Pembelajaran Matematika. FPMIPA: UPI.

Yuliana, E. (2015). Pengembangan Soal Open Ended pada Pembelajaran Matematika untuk Mengidentifikasi Kemampuan Berfikir Kreatif Siswa.

Yunianta, T.N., Rusilowati, A., \& R. (2012). Kemampuan Berpikir Kreatif Siswa pada Implementasi Project-Based Learning dengan Peer And SelfAssessment. Unnes Journal of Mathematics Education Research, 1(2), 8186. 